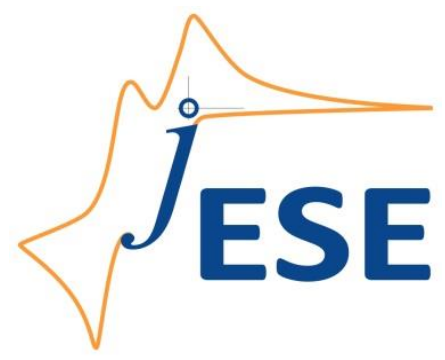

Open Access: ISSN 1847-9286

www.jESE-online.org

Original scientific paper

\title{
Electrodeposition of Bi-Se thin films involving ethylene glycol based electrolytes
}

\author{
Sevinj Piri Javadova, Vusala Asim Majidzade ${ }^{\bowtie}$, Akif Shikhan Aliyev, \\ Asmat Nizami Azizova and Dilgam Babir Tagiyev \\ Institute of Catalysis and Inorganic Chemistry named after acad. M. Nagıyev Azerbaijan National \\ Academy of Sciences (ANAS), Baku, AZ 1143, Azerbaijan
}

Corresponding author: ${ }^{凶}$ vuska 80@mail.ru, phone: +99450 6400225

Received: October 10, 2020; Revised: January 5, 2021; Accepted: January 6, 2021

\begin{abstract}
The work is devoted to the electrochemical deposition of Bi-Se thin films from ethylene glycol-based electrolytes. The studies have been carried out by potentiodynamic and galvanostatic methods under various conditions, using Pt and Ni electrodes. By recording cyclic and linear polarization curves, the potential ranges of deposition of thin Bi-Se films on Pt (-0.75 to -1.2 V) and $\mathrm{Ni}(0.2$ to $-0.85 \mathrm{~V})$ electrodes were determined. A comparison of the polarization curves of two electrodes showed that co-electrodeposition of Bi and Se occurs in approximately the same potential range. In order to find the optimal mode and composition of the electrolyte, the effect of various factors (concentration of initial components, temperature, etc.) on the process of co-electrodeposition of Bi with Se was studied. In addition, the samples of Bi-Se thin films obtained on Ni electrodes using the galvanostatic method were studied by scanning electron microscope (SEM) and X-ray phase analysis. The results of X-ray phase analysis confirmed the formation of thin $\mathrm{Bi}_{2} \mathrm{Se}_{3}$ films with and without additional heat treatment step. Elemental analysis of obtained films carried out by EDS shows that films contained 62.79 wt.\% Bi and 37.21 wt.\% Se.
\end{abstract}

\section{Keywords}

Bismuth (III) selenide; thin films; co-deposition; ethylene glycol; polarization

\section{Introduction}

The use of thin semiconductor films is widespread in the modern world [1-5]. They are applied in various fields of technology, microelectronics, and electronics for the production of photoresistors, laser materials, optical recording devices, etc., and also in solar cells for energy production and storage [6-7]. Therefore, finding new promising and optimal methods and conditions for obtaining of semiconducting thin films is quite important task. 
Bismuth selenide $\left(\mathrm{Bi}_{2} \mathrm{Se}_{3}\right)$ is a layered semiconductor with a straight band gap 0.3-0.4 eV in the monocrystalline form and 0.9-2.3 eV in a thin film [8-10]. $\mathrm{Bi}_{2} \mathrm{Se}_{3}$ is important member of $\mathrm{A}_{2} \mathrm{~V}_{3} \mathrm{VI}^{\mathrm{VI}}$ family of compounds and has high absorption coefficient in the visible and near-infrared regions. As an important $\mathrm{n}$-type chalcogenide, $\mathrm{Bi}_{2} \mathrm{Se}_{3}$ has many important characteristics such as high electrical conductivity [11], conspicuous thermoelectric property [12], photosensitivity [13], electrochemical property [8], and photoconductivity [14]. Besides, $\mathrm{Bi}_{2} \mathrm{Se}_{3}$ is a popular topological insulator [15-17] and has unique property of conducting surface states and isolated bulk states.

Up to now, to synthesize $\mathrm{Bi}_{2} \mathrm{Se}_{3}$, numerous methods, such as pulsed magnetron sputtering, molecular beam epitaxy, organometallic chemical vapor deposition, hydrothermal deposition, sequential ionic layer absorption and reaction, chemical deposition, electrochemical deposition, etc. have been used [18-25]. Electrochemical obtaining of semiconductor chalcogenide films is enlarging day by day, mostly due to several advantages of the deposition method. These advantages include short deposition time periods and reasonable operation temperatures. Moreover, through the proper selection of electrolyte composition, various types of the alloy may be obtained, allowing also the covering of large and complex substrates. Also, the parameters that affect electrochemical deposition process can be easily controlled, carrying out the studied process in the strictly desired direction. Application of electrochemical deposition does not require complex instruments, devices and procedures, and is therefore considered economically beneficial.

The present research aims to obtain thin films of semiconductor material $\mathrm{Bi}_{2} \mathrm{Se}_{3}$ by the electrochemical deposition method. Also, this work would be a certain continuation of our previous work about the electrochemical obtaining of chalcogenide compounds [2,4,26-31].

\section{Experimental}

The recording of potentiodynamic polarization curves was carried out using a potentiostat "IVIUMSTAT Electrochemical Interface", equipped with a computer programmed by the IviumSoftware. During potentiodynamic experiments, a three-electrode electrochemical cell with a volume of $100 \mathrm{ml}$ was used. As a working electrode, Pt wire with an area of $0.3 \mathrm{~cm}^{2}$ and a Ni-electrode with an area of $2 \mathrm{~cm}^{2}$ were taken. $A$ saturated silver/silver chloride $(\mathrm{Ag} / \mathrm{AgCl} / \mathrm{KCl})$ electrode was used as a reference electrode, and a Pt plate with an area of $4 \mathrm{~cm}^{2}$ was used as an auxiliary electrode. Experiments were performed at 313-323 $\mathrm{K}$.

The study of the morphology and determination of the elemental composition (energy dispersive spectroscopy, EDS) of the electrodeposited Bi-Se samples were carried out using the scanning electron microscope of Carl Zeiss Sigma brand (SEM).

The phase composition of the obtained thin layers was determined using an X-ray phase D2 Phazer analyzer from a Bruker company, Germany (CuK $\alpha$ filter, $\mathrm{Ni})$. The electrolyte used in the experiments was composed from $0.1 \mathrm{M} \mathrm{Bi}\left(\mathrm{NO}_{3}\right)_{3} \cdot 5 \mathrm{H}_{2} \mathrm{O}$ (supplied by JSC Vekton, Russia) and $0.03 \mathrm{M} \mathrm{H}_{2} \mathrm{SeO}_{3}$ (supplied by LLC Reachim, Russia), dissolved in ethylene glycol (supplied by PJSC Sibur-Neftechim, Russia).

Since Pt electrodes require periodic cleaning, before the experiments they were cleaned in concentrated nitric acid, and then rinsed with bi-distilled water. After each experiment, Pt electrode was kept for 30 minutes in the boiling nitric acid that contains a small amount of ferric chloride. After that, it was thoroughly washed with tap water, and then with distilled water. At the end, Pt electrode surface was rinsed with alcohol or acetone [32].

$\mathrm{Ni}$ electrodes were firstly polished electrochemically in the concentrated $\mathrm{HNO}_{3}$ acid, and then reduced in a solution consisting of $\mathrm{H}_{2} \mathrm{SO}_{4}, \mathrm{H}_{3} \mathrm{PO}_{4}$, and citric acids $\left(T=293-303 \mathrm{~K}, i=500 \mathrm{~mA} / \mathrm{cm}^{2}\right.$, $\tau=180 \mathrm{~s})$. At the end, they were thoroughly washed with distilled water [32]. 


\section{Results and discussion}

Electrodeposition of two components is more complex than deposition of individual components, because co-deposition requires stricter control of the electrolyte composition and deposition conditions. Therefore, prior to co-deposition experiments, it would be necessary to study deposition of initial components separately.

Figure 1 shows cyclic polarization curves of Pt electrode in the pure electrolyte (ethylene glycol), electroreduction of individual components ( $\mathrm{Bi}$ and $\mathrm{Se}$ ), and co-electrodeposition of $\mathrm{Bi}$ with Se. In comparison with an aqueous electrolyte, reduction processes in non-aqueous media occur at more negative potentials and with lower currents $[33,34]$. This is due to very low electrical conductivity of non-aqueous solutions, what prevents rapid arrival of ions to the electrode surface. In pure ethylene glycol solution (curve 1), Pt electrode is in almost polarizable state, and ions are accumulated at the surface forming electrical double-layer. The reduction of selenite $\left(\mathrm{SeO}_{3}{ }^{2-}\right)$ ions to $\mathrm{Se}^{2-}$ ions (curve 2) occurs in one stage with the observation of a cathodic plateau at potentials of -0.3 to $-0.5 \mathrm{~V}$, which should be assigned to the reduction of selenite ions. Electrochemical reduction of bismuth $\left(\mathrm{Bi}^{3+}\right)$ ions (curve 3 ) occurs within the potential interval of -0.05 to $-0.75 \mathrm{~V}$. At the potential of $-0.05 \mathrm{~V}, \mathrm{Bi}^{3+}$ ions are reduced to $\mathrm{Bi}^{0}$, and the first trace of bismuth appears on the Pt surface and with increasing potential, in a more negative direction the deposition of $\mathrm{Bi}$ is accelerated, and $\mathrm{Pt}$ surface becomes covered with a black layer.
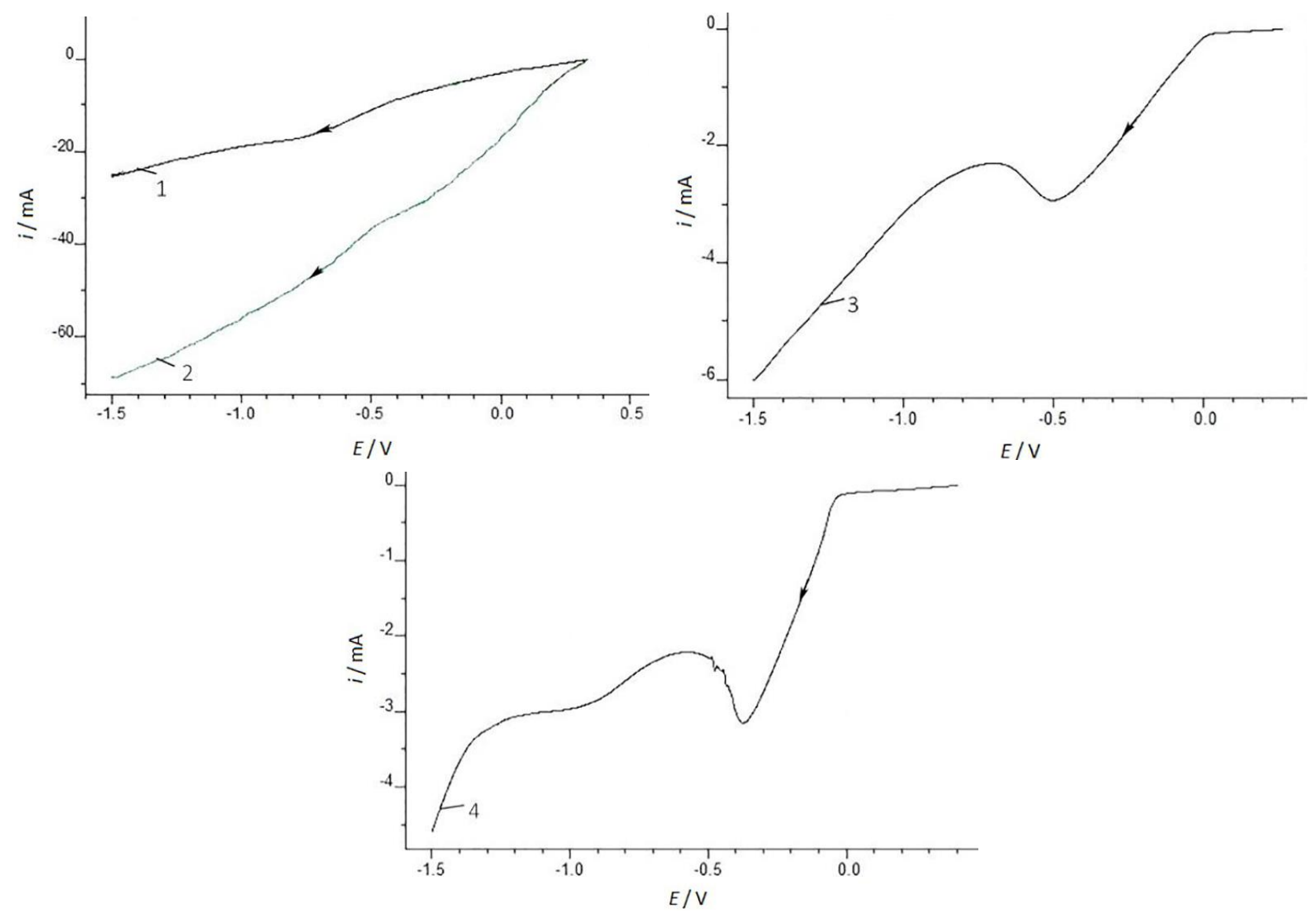

Figure 1. Cathodic polarization curves $\left(0.02 \mathrm{~V} \mathrm{~s}^{-1}\right)$ of Pt electrode in: ethylene glycol $\left(\mathrm{C}_{6} \mathrm{H}_{8} \mathrm{O}_{7}\right)$ (curve 1), $0.03 \mathrm{M} \mathrm{H}_{2} \mathrm{SeO}_{3}+\mathrm{C}_{6} \mathrm{H}_{8} \mathrm{O}_{7}$ (curve 2), $0.07 \mathrm{M} \mathrm{Bi}\left(\mathrm{NO}_{3}\right)_{3} \times 5 \mathrm{H}_{2} \mathrm{O}+\mathrm{C}_{6} \mathrm{H}_{8} \mathrm{O}_{7}$ (curve 3) and $0.07 \mathrm{M} \mathrm{Bi}\left(\mathrm{NO}_{3}\right)_{3} \times 5 \mathrm{H}_{2} \mathrm{O}+0.03 \mathrm{M} \mathrm{H}_{2} \mathrm{SeO}_{3}+\mathrm{C}_{6} \mathrm{H}_{8} \mathrm{O}_{7}$ (curve 4); $\mathrm{T}=298 \mathrm{~K}$.

Co-electrodeposition of bismuth with selenium (curve 4) from ethylene glycol on Pt electrode occurs within the potential range of -0.05 to $-1.5 \mathrm{~V}$ in two stages. Starting from $-0.05 \mathrm{~V}$ and down to $-0.6 \mathrm{~V}$, the electroreduction of $\mathrm{Bi}^{3+}$ ions occurs, while at about $-0.6 \mathrm{~V}$, co-deposition of $\mathrm{Bi}$ and $\mathrm{Se}$ 
occurs. With further potential decrease down to $-1.2 \mathrm{~V}$, electrochemical deposition is accelerated, the current consumed for the process is increased, and the electrode becomes completely covered with a black layer. In comparison with deposition potentials of individual $\mathrm{Bi}(-0.05 \mathrm{~V})$ and $\mathrm{Se}(-0.3 \mathrm{~V})$, their co-electrodeposition occurs at more anodic potential of $-0.6 \mathrm{~V}$.

The process of co-electrodeposition of bismuth with selenium has also been studied on a porous nickel electrode. From the comparison of cathodic polarization curves of Pt (Figure 1, curve 4) and Ni (Figure 2) electrodes in ethylene glycol containing $\mathrm{Bi}$ and $\mathrm{Se}$ ions, it is clear that co-electrodeposition of $\mathrm{Bi}$ and $\mathrm{Se}$ on $\mathrm{Ni}$ electrode occurs by forming the cathode plateau at potentials of -0.4 to $-0.85 \mathrm{~V}$.

After determining the potential range of co-deposition, the effect of various factors on the process was studied by the potentiodynamic method to find the optimal electrolysis mode and electrolyte composition. As is already known, one of the main factors affecting the electrochemical process is temperature. The effect of temperature on the co-deposition process was studied in the range of $298-338 \mathrm{~K}$.

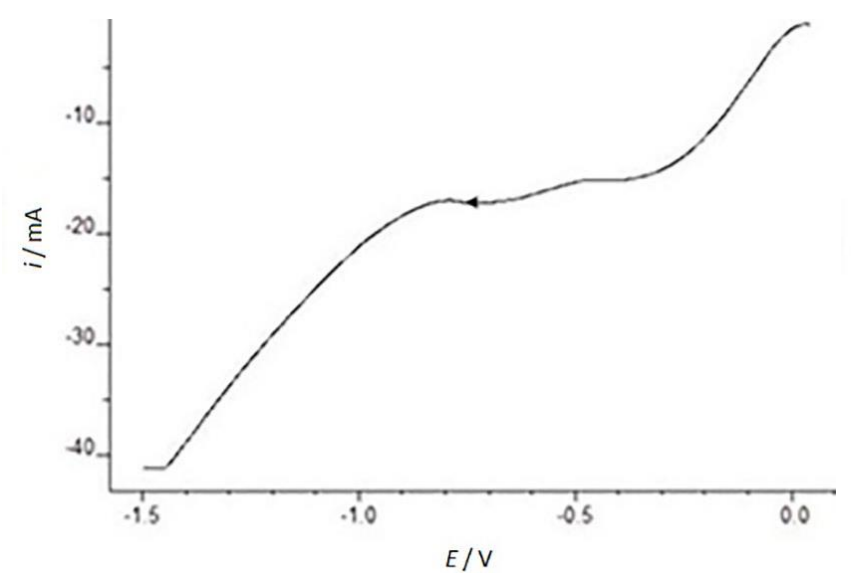

Figure 2. Cathodic polarization curve $\left(0.02 \mathrm{Vs}^{-1}\right)$ of co-deposition of Bi with Se on Ni electrode. Electrolyte composition (M):

$0.07 \mathrm{Bi}\left(\mathrm{NO}_{3}\right)_{3} \times 5 \mathrm{H}_{2} \mathrm{O}+0.03 \mathrm{H}_{2} \mathrm{SeO}_{3}+\mathrm{C}_{6} \mathrm{H}_{8} \mathrm{O}_{7} ; \mathrm{T}=298 \mathrm{~K}$.

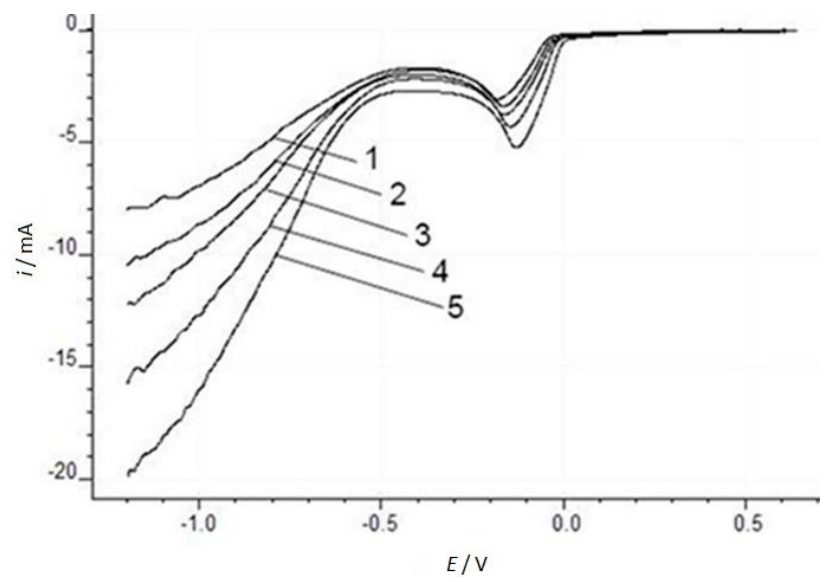

Figure 3. Cathodic polarization curves $\left(0.02 \mathrm{Vs}^{-1}\right)$ of co-deposition of Bi with Se on Pt electrode from ethylene glycol solution containing $\left(0.07 \mathrm{M} \mathrm{Bi}\left(\mathrm{NO}_{3}\right)_{3} \times 5 \mathrm{H}_{2} \mathrm{O}+0.03 \mathrm{M} \mathrm{H}_{2} \mathrm{SeO}_{3}\right)$ at $\mathrm{T} / \mathrm{K}=298$ (1), 308 (2), 318 (3), 328 (4), 338 (5).

Cathodic polarization curves of the experiments shown in Figure 3 demonstrate that with increasing of temperature, the beginning of co-electrodeposition of bismuth with selenium is shifted positively to $0.0 \mathrm{~V}$, while the current spent on the process increased up to $-20 \mathrm{~mA}$.

The influence of the concentration of initial components was studied separately. The effect of the concentration of bismuth ions was investigated in the range of $0.05-0.11 \mathrm{~mol} / \mathrm{L}$, keeping the concentration of selenium ions constant. The research results are presented in Figure 4, showing that with an increase in the concentration of $\mathrm{Bi}$ ions, the potential of electrodeposition moved towards a positive direction. Also, with an increase in the number of bismuth ions in the electrolyte, co-deposition was accelerated, and the current consumed on the process increased.

A similar situation is seen in Figure 5 showing cathodic polarization curves of co-electrodeposition process of $\mathrm{Bi}$ and Se for different concentrations of selenite ions at the constant concentration of bismuth ions. The influence of the concentration of selenite ions was studied in the range 0.018-0.054 $\mathrm{mol} / \mathrm{L}$. As is seen from Figure 5, with an increase in the concentration of selenite ions, the process of co-deposition also accelerates. In this case, however, acceleration affects detrimentally onto stoichiometric composition and quality of the obtained thin layers. Hence, it has been determined by 
experiments that thin films close to the stoichiometric composition are obtained at $0.07 \mathrm{~mol} / \mathrm{L}$ concentration of bismuth ions and $0.03 \mathrm{~mol} / \mathrm{L}$ concentration of selenite ions.

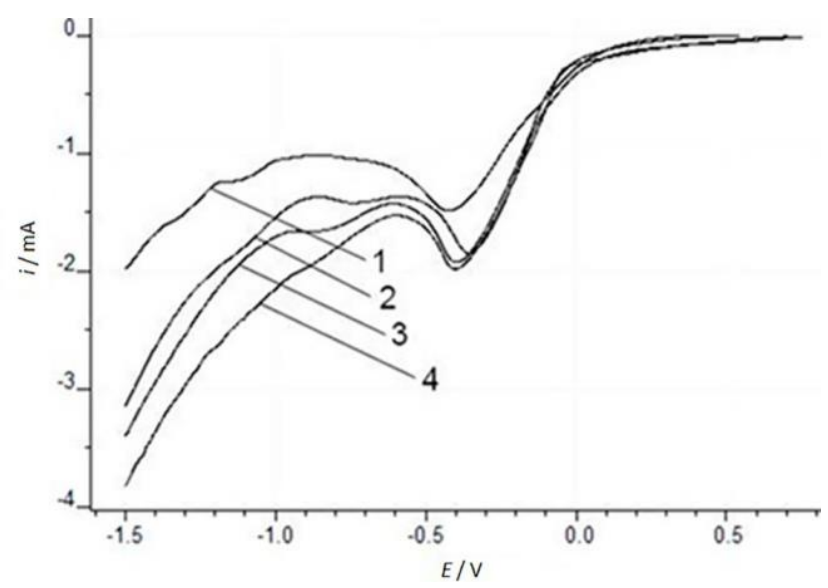

Figure 4. Cathodic polarization curves $\left(0.02 \mathrm{~V} \mathrm{~s}^{-1}\right)$ of co-deposition of Bi with Se on Pt electrode from ethylene glycol solution containing $0.03 \mathrm{M} \mathrm{H}_{2} \mathrm{SeO}_{3}$ and different concentrations of $\mathrm{Bi}\left(\mathrm{NO}_{3}\right)_{3} \times 5 \mathrm{H}_{2} \mathrm{O}(\mathrm{M})$ : 0.05 (1), 0.07 (2), 0.09 (3), 0.11 (4); $\mathrm{T}=298 \mathrm{~K}$.

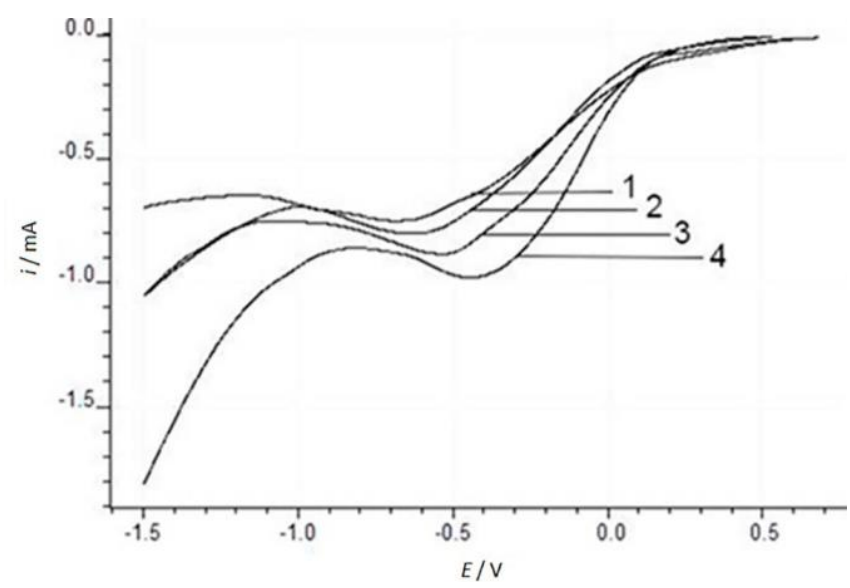

Figure 5. Cathodic polarization curves $\left(0.02 \mathrm{~V} \mathrm{~s}^{-1}\right)$ of co-deposition of $\mathrm{Bi}$ with Se on Pt electrode from ethylene glycol solution containing $0.07 \mathrm{M} \mathrm{Bi}\left(\mathrm{NO}_{3}\right)_{3} \times 5 \mathrm{H}_{2} \mathrm{O}$ and different concentrations of $\mathrm{H}_{2} \mathrm{SeO}_{3}(\mathrm{M})$ :

0.018 (1), 0.03 (2), 0.042 (3), 0.054 (4); T = $298 \mathrm{~K}$.

After determining the potential range and studying the influence of some factors on the process of co-deposition of thin Bi-Se films, the samples were deposited on Ni electrode in the galvanostatic mode at the current density of $9-10 \mathrm{~mA} / \mathrm{cm}^{2}$.

Figure 6 shows $\mathrm{X}$-ray diffraction pattern, morphology, and elemental composition of the obtained Bi-Se film.
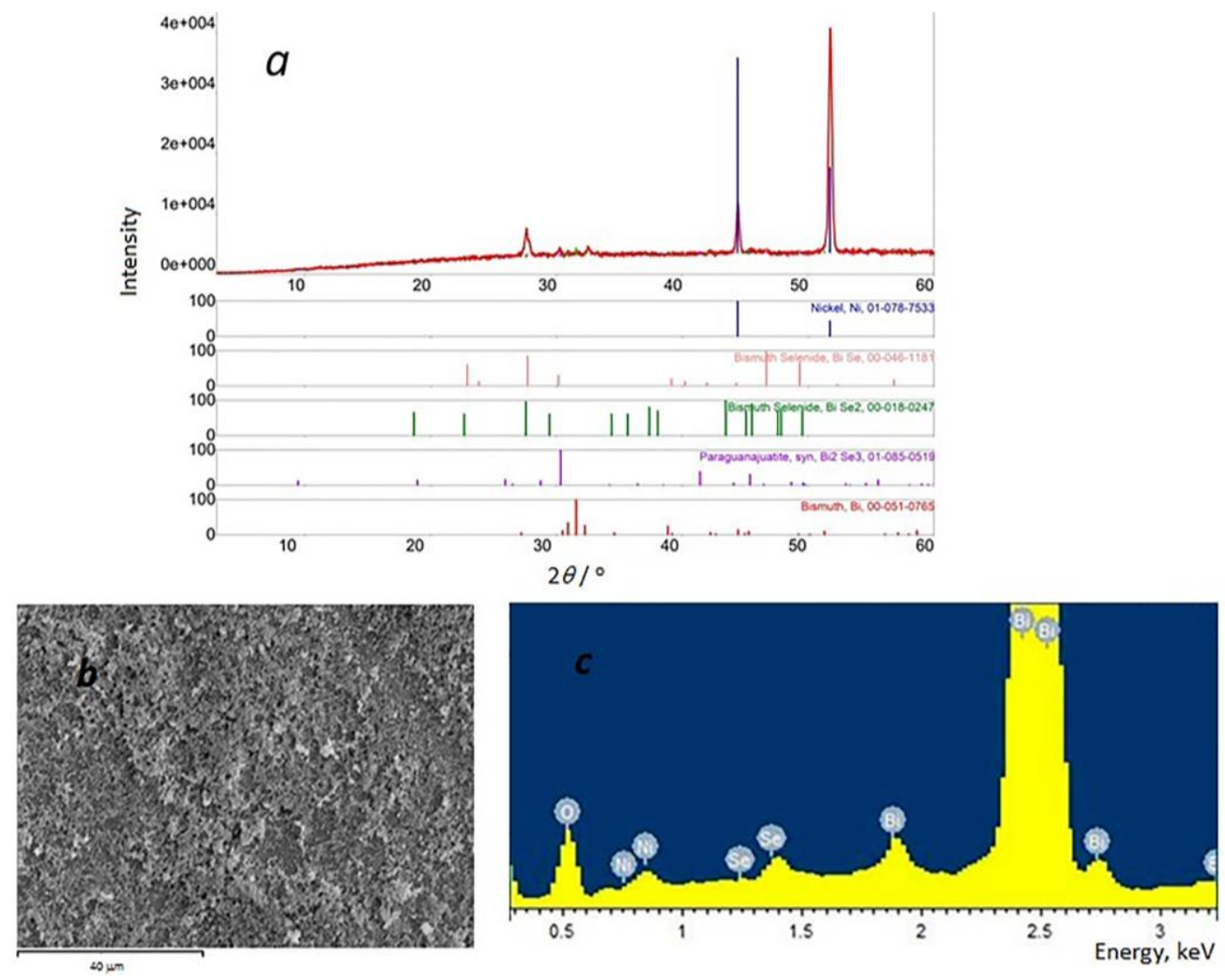

Figure 6. (a) X-ray pattern, (b) morphology and (c) EDS spectrum of Bi-Se film formed on Ni electrode by co-deposition from ethylene glycol containing $0.07 \mathrm{M} \mathrm{Bi}\left(\mathrm{NO}_{3}\right)_{3} \times 5 \mathrm{H}_{2} \mathrm{O}+0.03 \mathrm{M} \mathrm{H}_{2} \mathrm{SeO}_{3} ; \mathrm{T}=298 \mathrm{~K}$. 
Using X-ray analysis, it has been established that $\mathrm{Bi}_{2} \mathrm{Se}_{3}$ thin films are obtained as a result of these experiments. The diffraction peaks observed in Figure 6 a at $2 \theta$ angles close to $\sim 18^{\circ}, \sim 29^{\circ}, \sim 38^{\circ}$ and $\sim 58^{\circ}$, respectively are proper to rhombohedral $\mathrm{Bi}_{2} \mathrm{Se}_{3}$. Clear peaks observed at $2 \theta \sim 45^{\circ}$ and $\sim 52^{\circ}$ belong to $\mathrm{Ni}$ substrate.

The size of grains is changed within a fraction of 1 to 5 microns that is shown in Figure $6 \mathrm{~b}$. The variation in the size of various grains is due to high porosity of $\mathrm{Ni}$ substrate that allows them to grow freely during deposition. The elemental content presented in Figure $6 c$ indicates that the film mainly consists of $\mathrm{Bi}$ and $\mathrm{Se}$, what demonstrates its chemical purity. EDS data show that film contains $62.79 \mathrm{wt} . \% \mathrm{Bi}$ and $37.21 \mathrm{wt} . \% \mathrm{Se}$. The presence of nickel atoms in the spectrum is due to $\mathrm{Ni}$ substrate. As is commonly seen from Figure 6, the results of freshly deposited film confirm the deposition of $\mathrm{Bi}_{2} \mathrm{Se}_{3}$ films.

Figure 7 presents the results for the deposited film thermally treated at $673 \mathrm{~K}$ in argon medium for 30 minutes. X-ray pattern (Figure 7a), SEM image (Figure 7b) and EDS results (Figure 7c) show not much changes compared to Figure 6. It seems, however, that after the thermal treatment, $\mathrm{Bi}_{2} \mathrm{Se}_{3}$ film becomes more crystalline. Therefore, depending on the field of application, thin semiconductor films of $\mathrm{Bi}_{2} \mathrm{Se}_{3}$ can be obtained by either heat treatment or without it.
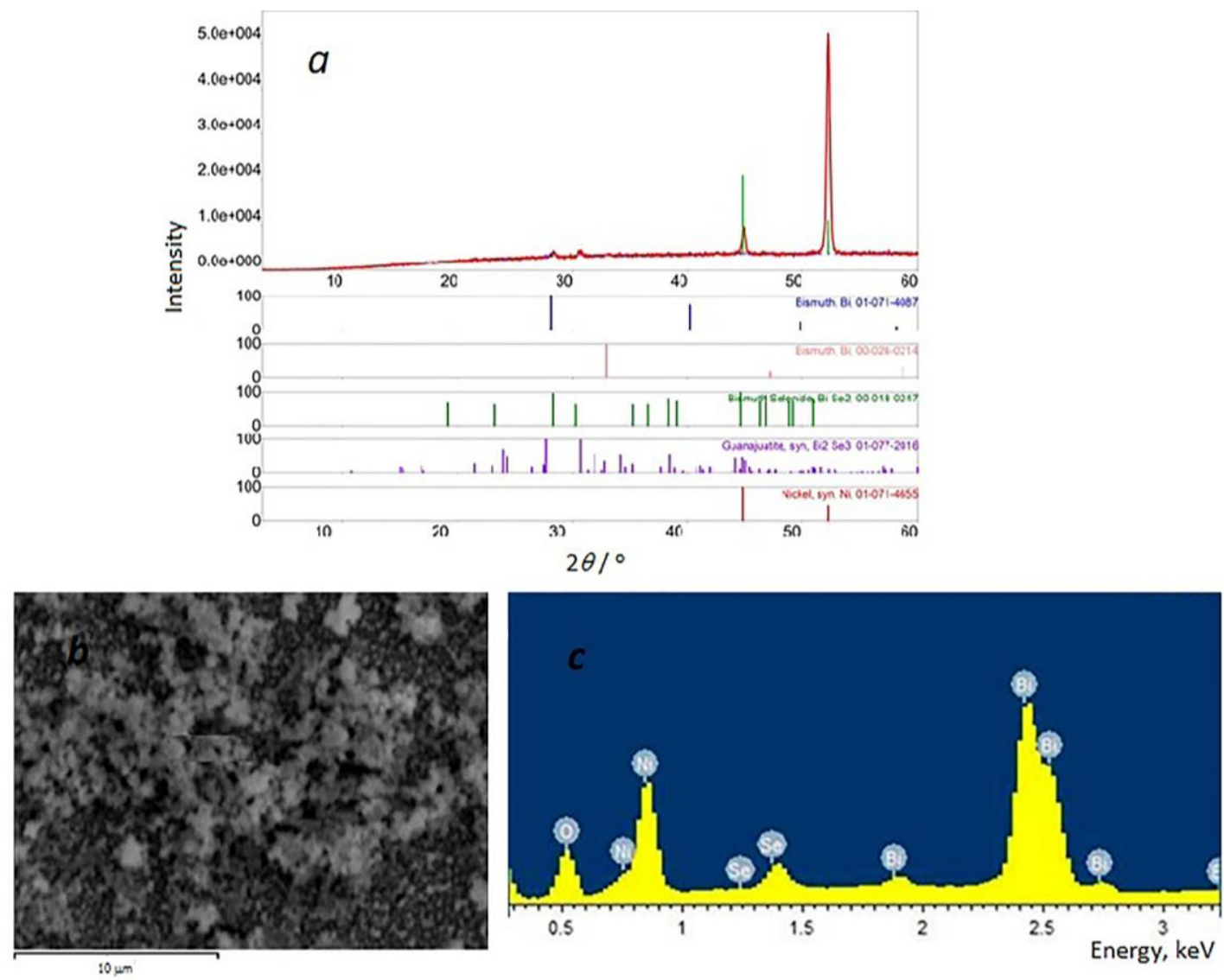

Figure 7. (a) X-ray pattern, (b) SEM image and (c) EDS spectrum of $\mathrm{Bi}_{2} \mathrm{Se}_{3}$ thin film presented in Figure 6 after heat treatment at $673 \mathrm{~K}$.

\section{Conclusion}

Electrochemical co-deposition of bismuth and selenium on Pt and Ni electrodes from ethylene glycol was investigated by the potentiodynamic method. Co-deposition of bismuth with selenium from ethylene glycol on Pt electrode occurs at the potential -0.6 V. On Ni electrode, co-deposition is carried out with a cathode plateau formed in the potential range of -0.4 to $-0.85 \mathrm{~V}$. To find the 
optimal mode and composition of the electrolyte, the influence of various factors (concentration of initial components, temperature, etc.) on the co-deposition process was studied. According to the experimental results, the electrolyte with the composition of $0.07 \mathrm{Bi}\left(\mathrm{NO}_{3}\right)_{3} \times 5 \mathrm{H}_{2} \mathrm{O}+$ $+0.03 \mathrm{H}_{2} \mathrm{SeO}_{3}+\mathrm{C}_{6} \mathrm{H}_{8} \mathrm{O}_{7}$ and $T=298 \mathrm{~K}$ can be used to obtain thin films of $\mathrm{Bi}_{2} \mathrm{Se}_{3}$ with a composition close to the stoichiometric ratio.

The deposits were also exposed to thermal treatment at $673 \mathrm{~K}$ in argon atmosphere. For both fresh and thermally treated samples, formation of thin $\mathrm{Bi}_{2} \mathrm{Se}_{3}$ films was confirmed. Films that undergone thermal treatment, however, was found more crystalline.

Acknowledgement: This work was carried out with the financial support of the National Academy of Sciences of Azerbaijan within the framework of research programs in priority areas in 2019-2020.

\section{References}

[1] R. Henríquez, C. Vasquez, N. Briones, E. Muñoz, P. Leyton, E. A. Dalchiele, International Journal of Electrochemical Science 11 (2016) 4966-4978 https://dx.doi.org/10.20964/2016.06.17.

[2] A. Sh. Aliyev, M. Elrouby, S. F. Cafarova, Materials Science in Semiconductor Processing 32 (2015) 3139 https://doi.org/10.1016/j.mssp.2015.01.006.

[3] A. H. Munshi, N. Sasidharan, S. Pinkayan, K. L. Barth, W. S. Sampath, W. Ongsakul, Solar Energy 173 (2018) 511-516 https://doi.org/10.1016/i.solener.2018.07.090.

[4] A. Sh. Aliyv, V. A. Majidzade, N. Sh. Soltanova, D. B. Tagiyev, V. N. Fateev, Chemical Problems 16 (2018) 178-185 https://doi.org/10.32737/2221-8688-2018-2-178-185.

[5] G. M. Hüseynov, N. A. Mammadova, H. A. Imanov, Chemical Problems 15 (2017) 329-334 https://doi.org/10.32737/2221-8688-2017-3-329-334.

[6] V. N. Fateev, O.K. Alexeeva, S. V. Korobtsev, E. A. Seregina, T. V. Fateeva, A. S. Grigoriev, A. Sh. Aliyev, Chemical Problems 16 (2018) 453-483 https://doi.org/10.32737/2221-8688-2018-4-453-483.

[7] T. L. Kulova, I. I. Nikolaev, V. N. Fateev, A. Sh. Aliyev, Chemical Problems 16 (2018) 9-34 https://doi.org/10.32737/2221-8688-2018-1-9-34.

[8] S. D. Kharade, N. B. Pawar, V. B. Ghanwat, S. S. Mali, W. R. Bae, P. S. Patil, C. K. Hong, J. H. Kim, P. N. Bhosale, New Journal of Chemistry 37 (2013) 2821-2828 https://doi.org/10.1039/C3NJ00463E.

[9] Y. Min, G. D. Moon, B. S. Kim, B. Lim, J. Kim, C. Y. Kang, U. Jeong, Journal of the American Chemical Society 134 (2012) 2872-2875 https://doi.org/10.1021/ja209991z.

[10] B. Pejova, I. Grozdanov, Thin Solid Films 408 (2002) 6-10 https://doi.org/10.1016/S0040-6090(02)$\underline{00085-8 .}$

[11] Z. L. Sun, S. C. Liufu, L. D. Chen, Dalton Transactions 39 (2010) 10883-10887 https://doi.org/10.1039/CODT00840K.

[12] Z. L. Sun, S. C. Liufu, X. H. Chen, L. Chen, CrystEngComm 12 (2010) 2672-2674 https://doi.org/10.1039/C002523B.

[13] J. Waters, D. Crouch, J. Raftery, P. O'Brien, Chemistry of Materials 16 (2004) 3289-3298 https://doi.org/10.1021/cm035287o.

[14] N. D. Desai, V. B. Ghanwat, K. V. Khot, S. Mali, C. Hong, P. N. Bhosale, Journal of Materials Science: Materials in Electronics 27 (2016) 2385-2393 https://doi.org/10.1007/s10854-015-4036-6.

[15] L. Braun, G. Mussler, A. Hruban, M. Konczykowski, T. Schumann, M. Wolf, M. Münzenberg, L. Perfetti, T. Kampfrath, Nature Communications 7 (2016) 13259 https://doi.org/10.1038/ncomms13259.

[16] C. Liu, H. B. Zhang, Z. Sun, K. Ding, J. Mao, Z. Shao, J. Jie, Journal of Materials Chemistry C 4 (2016) 5648-5655 https://doi.org/10.1039/C6TC01083K.

[17] L. D. Alegria, J. R. Petta, Nanotechnology 23 (2012) 435601 https://doi.org/10.1088/0957-4484/23/$\underline{43 / 435601 .}$

[18] H. Liu, H. Cui, F. Han, X. Li, J. Wang, R. I. Boughton, Crystal Growth Design 5 (2005) 1711-1714 https://doi.org/10.1021/cg049907p.

[19] L. Meng, H. Meng, W. Gong, W. Liu, Z. Zhang, Thin Solid Films 519 (2011) 7627-7631 https://doi.org/10.1016/i.tsf.2011.04.239. 
[20] C. Xiao, J. Yang, W. Zhu, J. Peng, J. Zhan, Electrochimica Acta 54 (2009) 6821-6826 https://doi.org/10.1016/i.electacta.2009.06.089.

[21] O. C. Monteiro, T. Trindade, F. A. Paz, J. Klinowski, J. Watersc, P. O. Brien, Journal of Materials Chemistry 13 (2003) 3006-3010 https://doi.org/10.1039/B306662M.

[22] H. Cuia, H. Liu, X. Lia, J. Wang, F. Han, X. Zhang, R. I. Boughton, Journal of Solid State Chemistry 177 (2004) 4001-4006 https://doi.org/10.1016/j.jssc.2004.06.042.

[23] C. Han, J. Yang, C. Yan, Y. Li, F. Liu, L. Jiang, J. Ye, Y. Liua, CrystEngComm 16 (2014) 2823-2827 https://doi.org/10.1039/C3CE42056F.

[24] C. D. Lokhanade, B. R. Sankpal, S. D. Sartale, H. M. Pathan, M. Giersig, V. Ganeshan, Applied Surface Science 181 (2001) 413-417 https://doi.org/10.1016/S0169-4332(01)00461-5.

[25] P. K. Nair, M. T. S. Nair, V. M. Garcia, O. L. Arenas, Y. Pena, A. Castillo, I. T. Ayala, O. Gomezdaza, A. Sanchez, J. Campos, H. Hu, R. Suarez, M. E. Rincon, Solar Energy Materials and Solar Cells 52 (1998) 313-344 https://doi.org/10.1016/S0927-0248(97)00237-7.

[26] V. A. Majidzade, Chemical Problems 16 (2018) 331-336 https://doi.org/10.32737/2221-8688-2018-3$\underline{331-336 .}$

[27] V. A. Majidzade, A. Sh. Aliyev, I. Qasimogli, P. H. Quliyev, D. B. Tagiyev, Inorganic Materials 55 (2019) 979-983 https://doi.org/10.1134/S0020168519100108.

[28] V. A. Majidzade, A. Sh. Aliyev, P. H. Guliyev, D. M. Babanly, Journal of Electrochemical Science and Engineering 10 (2020) 1-9 http://dx.doi.org/10.5599/jese.676.

[29] V. A. Majidzade, A. Sh. Aliyev, D. B. Tagiyev, Bulgarian Chemical Communications 52 (2020) 69-74

[30] V. A. Majidzade, S. F. Cafarova, A. Sh. Aliyev, N. B. Farhatova, Y. A. Nuriyev, D. B. Tagiyev, Azerbaijan Chemical journal 1 (2019) 6-13 http://dx.doi.org/10.32737/0005-2531-2019-1-6-13.

[31] V. A. Majidzade, S. F. Cafarova, A. Sh. Aliyev, D. B. Tagiyev, Azerbaijan Chemical Journal 3 (2018) 6-10 http://dx.doi.org/10.32737/0005-2531-2018-3-6-10.

[32] V. F. Barkovsky, T. B. Gorodentseva, N. B. Toporova, Fundamentals of Physical and Chemical Methods of Analysis, M: Higher School, Russia, 1983, p. 247.

[33] V. A. Majidzade, A. Sh. Aliyev, P. H. Guliyev, Y. N. Babayev, M. Elrouby, D. B. Tagiyev, Journal of Electrochemical Science and Engineering 8 (2018) 197-204 https://doi.org/10.5599/jese.490.

[34] V. A. Majidzade, P. H. Quliyev, Y. Babayev, A. Sh. Aliyev, Nakhchivan State University Scientific Works 80 (2016) 140-144.

C 2021 by the authors; licensee IAPC, Zagreb, Croatia. This article is an open-access article distributed under the terms and conditions of the Creative Commons Attribution license (https://creativecommons.org/licenses/by/4.0/) 